\title{
Mengelola Human Resource dalam Dunia Digital untuk Memperoleh Workforce yang Unggul dalam Mengelola Bisnis Start-Up Bidang Jasa
}

\author{
Robertus Adi Nugroho \\ Mahasiswa Pasca Sarjana Universitas Katolik Widya Mandala Surabaya \\ Email: robertusadiop@gmail.com
}

\begin{abstract}
Artikel info
Artikel history:

Diterima 03 Mei 2021

Diterima dalam bentuk

revisi 09 Mei 2021

Diterima dalam bentuk revisi 18 Mei 2021

Keywords:

MSDM; digital era; MSDM

4.0; start-up; digital human resource.

Abstrak

The economic world is facing the dawn of a new era, the Information Era. Since the industrial revolution 4.0 emerged, many companies all over the world have been looking for a new ways to manage their human resource. Digital Technology emerge as one of the top list. Managing human resource in a digital era required a new perspective and approach. Human resource should be considered not only as a cost, but also as an investation for organization. Managing them correctly could give organization a great competitive advantage in their business. The questions is just how to manage this human resource correctly in this new era? First, the company needs have a great synergy between Human Resource Department and company managerial system. Second, they need to put human resource as a strategic value for the future of the company. Third, the company needs to motivate their employee in certain way to increase their work power. This paper presents a textual study, identification and analysis of how a company, especially a start-up company can manage their people correctly in this $d$ igital era to achieve a valuable and strong workforce.
\end{abstract}

Kata Kunci:

MSDM; digital era; MSDM 4.0; start-up; digital human resource.

\begin{abstract}
Abstrak
Dunia ekonomi sedang menghadapi fajar era baru, Era Informasi. Sejak revolusi industri 4.0 muncul, banyak perusahaan di seluruh dunia mencari cara baru untuk mengelola sumber daya manusia mereka. Teknologi Digital muncul sebagai salah satu daftar teratas. Mengelola sumber daya manusia di era digital membutuhkan cara pandang dan pendekatan baru. Sumber daya manusia harus dianggap tidak hanya sebagai biaya, tetapi juga sebagai investasi bagi organisasi. Mengelola mereka dengan benar dapat memberi organisasi keunggulan kompetitif yang besar dalam bisnis mereka. Pertanyaannya tinggal bagaimana cara mengelola sumber daya manusia ini dengan benar di era baru ini? Pertama, perusahaan perlu memiliki sinergi yang baik antara Departemen Sumber Daya Manusia dengan sistem manajerial perusahaan. Kedua, mereka perlu menempatkan sumber daya manusia sebagai nilai strategis untuk masa depan perusahaan. Ketiga, perusahaan perlu memotivasi karyawannya dengan cara tertentu untuk meningkatkan daya kerjanya. Penelitian ini memaparkan kajian tekstual, identifikasi dan analisis bagaimana sebuah perusahaan, khususnya perusahaan rintisan dapat mengelola karyawannya dengan benar di era digital ini untuk mencapai tenaga kerja yang berharga dan kuat.
\end{abstract}

Coresponden author: Robertus Adi Nugroho, S. Fil. Email: robertusadiop@gmail.com artikel dengan akses terbuka dibawah lisensi 


\section{Pendahuluan}

Bekerja di ranah Sumber Daya Manusia atau Human Resource merupakan proses yang menyenangkan sekaligus menantang. Dalam 30 tahun terakhir, ada banyak sekali perubahan serta dinamika yang telah terjadi pada dunia MSDM (Manajemen Sumber Daya Manusia). Divisi Sumber Daya Manusia atau yang lebih sering disebut sebagai HRD (Human Resource Department) telah banyak berevolusi, dari yang awalnya hanya memegang peranan administrator, menjadi sebuah divisi penting yang sangat mempengaruhi suksesnya sebuah bisnis atau perusahaan. HRD mulai digunakan dalam proses usaha/bisnis, tugas HRD hanyalah sebagai sistem pendukung (support system) dalam perusahaan. HRD bertugas sebagai back-office yang mengurus perihal legalitas dokumen, pengurusan gaji, dan pengurusan data karyawan. Akan tetapi di masa kini, banyak perusahaan yang menaruh peranan penting pada Sumber Daya Manusia sebagai variabel penentu kesuksesan perusahaan. Tenaga kerja yang berkualitas diikuti dengan ekosistem kerja yang positif tidak hanya menarik perhatian talenta muda yang sedang mencari kerja di luar sana, melainkan juga dapat menarik perhatian konsumen terhadap produk atau jasa yang ditawarkan perusahaan (Fonna, 2019).

Iklim ekonomi yang sangat sulit untuk diprediksi masa ini, pengelolaan sumber daya manusia menjadi aspek yang berperan penting dalam menentukan arah dan tujuan perusahaan. HRD menjadi ujung tombak perusahaan dalam menjala karyawan yang kompeten dan berkemampuan tinggi. Bahkan tidak jarang perusahaan mulai menanamkan 'human capital approach', di mana perusahaan rela mengeluarkan biaya tinggi untuk mengembangkan dan meningkatkan kemampuan tenaga kerjanya. Perusahaan masa kini pun tidak ragu untuk memasukkan pengeluaran untuk mengembangkan sumber daya manusianya, sebagai bentuk investasi bagi perusahaan di masa yang akan datang. Tenaga kerja adalah aset perusahaan, dan seperti aset perusahaan lainnya, tenaga kerja harus dikelola, dilindungi dan dikembangkan sebaik mungkin (Riniwati, 2016).

\section{Perubahan ke Era Digital}

Seperti halnya peranan HRD yang terus berubah dari waktu ke waktu, teknologi pun terus menerus berevolusi. Teknologi di masa kini seakan menawarkan kemungkinan yang tak terbatas. Perkembangan teknologi membawa serta peluang akan kemudahan dan efisiensi bagi industri bisnis inilah yang kita sebut sebagai era digital. Era di mana keseharian manusia tidak bisa dilepaskan dari teknologi, internet, dan computer (Savitri, 2019).

Pada era digital seperti ini, manusia secara umum memiliki gaya hidup baru yang tidak bisa dilepaskan dari perangkat yang serba elektronik. Teknologi menjadi alat yang mampu membantu sebagian besar kebutuhan manusia. Teknologi telah dapat digunakan oleh manusia untuk mempermudah melakukan apapun tugas dan pekerjaan. Peran penting teknologi inilah yang membawa peradaban manusia memasuki era digital. Era digital telah membawa berbagai perubahan yang baik sebagai dampak positif yang bisa gunakan sebaik- baiknya. Namun dalam waktu yang bersamaan, era digital juga membawa banyak dampak negatif, sehingga menjadi tantangan baru dalam kehidupan manusia di era digital ini (Reza \& Hermawansyah, 2019).

Tantangan pada era digital telah pula masuk ke dalam berbagai bidang seperti politik, ekonomi, sosial budaya, pertahanan, keamanan, dan teknologi informasi itu sendiri. Era digital terlahir dengan kemunculan digital, jaringan internet khususnya teknologi informasi 
komputer. Semakin canggihnya teknologi digital masa kini membuat perubahan besar terhadap dunia, lahirnya berbagai macam teknologi digital yang semakin maju telah banyak bermunculan. Berbagai kalangan telah dimudahkan dalam mengakses suatu informasi melalui banyak cara, serta dapat menikmati fasilitas dari teknologi digital dengan bebas dan terkendali. Era digital juga membuat ranah privasi orang seolah-olah hilang. Data pribadi yang terekam di dalam otak komputer membuat penghuni internet mudah dilacak, baik dari segi kebiasaan berselancar atau hobi. Era digital bukan persoalan siap atau tidak dan bukan pula suatu opsi namun sudah merupakan suatu konsekuensi. Teknologi akan terus bergerak ibarat arus laut yang terus berjalan ditengah-tengah kehidupan manusia. Maka tidak ada pilihan lain selain menguasai dan mengendalikan teknologi dengan baik dan benar agar memberi manfaat yang sebesar-besarnya.

Pengelolaan dan pengembangan sumber daya manusia pun sudah tidak bisa dilepaskan dari teknologi digital. Seiring dengan terbukanya pemikiran dan ketergantungan manusia pada teknologi, maka lingkungan kerja pun dituntut untuk mau terbuka dengan era digital. Dalam pengelolaan tenaga kerja, HRD pun sudah banyak terlibat dengan teknologi. Teknologi menyediakan jalan bagi HRD untuk menjadi lebih efisien dan cerdas dalam mengelola sumber daya manusia. Jika HRD adalah support system bagi perusahaan, maka teknologi juga merupakan support system bagi HRD untuk menjalankan tugasnya.

Mungkin orang-orang yang berkecimpung dalam dunia HRD mengetahui bahwa pengelolaan tenaga kerja di masa kini tidak bisa dilepaskan dari penyusunan folder data yang serba rumit dan juta otomatisasi di banyak sisi. Rangkaian sistem di HRD sudah berpadu dengan system digital, yang mampu menampung, mengelola dan menyediakan informasi secara komprehensif bagi perusahaan dikala membutuhkan. Bahkan perusahaan tidak hanya memanfaatkan teknologi digital untuk HRD saja, melainkan juga untuk keseluruhan operasi karyawan sehari-harinya. Teknologi menjadi daya dongkrak yang sungguh mampu meningkatkan kinerja berbagai area di perusahaan.

\section{Munculnya Perusahaan Start-up}

Masuknya industri bisnis dalam era digital menuntut manusia untuk semakin kreatif dalam menawarkan barang atau jasa. Sekarang ini mungkin kita tidak asing lagi dengan istilah start-up. Istilah Start-up yang diartikan sebagai perusahaan baru yang sedang dikembangkan, mulai berkembang akhir tahun 90an hingga tahun 2000, nyatanya istilah Start-up banyak dikaitkan dengan segala yang berbau teknologi, web,internet dan yang berhubungan dengan ranah tersebut (Widodo, 2020).

Bertambahnya pengguna internet di berbagai belahan dunia merupakan salah satu faktor utama munculnya bisnis start-up ini. Di Indonesia saja, pengguna internet setiap tahunnya mengalami kenaikan yang drastic. Data emarketer menyebutkan bahwa Indonesia menduduki peringkat ke- 6 dalam Negara dengan pertumbuhan pengguna internet tercepat di dunia. Maka tidaklah aneh jika di Negara dengan pengguna internet yang besar seperti Indonesia, banyak perusahaan start-up yang bermunculan. Perusahaan start-up banyak bergerak di bidang penyediaan produk dan jasa. Akan tetapi diantara keduanya, bidang jasa tampaknya masih menjadi area favorit perusahaan start-up. Di Indonesia saja, mayoritas perusahaan start-up bergerak di bidang penyediaan jasa. Sebut saja, Go-jek, Tokopedia, Traveloka, Bukalapak, adalah perusahaan start-up besar di Indonesia yang sukses dalam 
penyediaan jasa (Astuti, 2019).

Membangun bisnis start-up di bidang jasa tidaklah mudah. Butuh keberanian dan keterampilan manajemen yang baik untuk memulai sebuah start-up dari nol. Pada era modern ini bisnis start-up atau yang juga dikenal dengan nama bisnis rintisan sudah mulai banyak digeluti oleh pebisnis muda. Dengan nuansa millennial yang selalu diusung start-up, banyak anak muda yang tertarik untuk bergabung dan mengembangkan bisnis ini. Dampaknya pun sungguh terasa, aktivitas start-up dengan cepat mendongkrak perekonomian nasional dan dunia. Keempat Unicorn yang ada di Indonesia saja (Gojek, Tokopedia, Traveloka, bukalapak), ditaksir memiliki valuasi bernilai 13,8 miliar dolar AS pada akhir tahun 2018 . Bahkan hingga awal 2020, jumlah start-up ini terus bertambah. Tidak kurang dari 10 start-up telah mengembangkan sayapnya di industri perekonomian digital Indonesia, dengan nilai valuasi tertinggi sebesar 4,8 miliar dolar AS. Nilai ini sungguh besar dan berhasil memimpin perekonomian Asia Tenggara dalam 2 tahun terakhir.

Dibalik kesuksesan sebuah bisnis start-up seperti ini, kita tidak dapat melupakan orangorang jenius yang bekerja keras di dalamnya. Seorang entrepreneur yang bergerak dibidang start-up harus memiliki visi dan motivasi yang luar biasa dalam merintis bisnisnya. Pengelolaan risiko, pengambilan inisiatif, manajemen sumber daya manusia, adalah sedikit dari sekian banyak hal yang harus diperhatikan seorang pemimpin start-up dalam upaya memajukan serta mengembangkan bisnisnya. Sekalipun bergerak dalam bidang digital, sumber daya manusia tetap menjadi unsur yang sangat penting dalam bisnis start-up. Persaingan yang sangat ketat dan tuntutan kerja yang tinggi menjadi salah satu alasan pentingnya pengelolaan sumber daya manusia dalam start-up.

Status Unicorn bahkan Decacorn pun tidak akan menjamin kesuksesan bisnis start-up jika dalam kenyataannya perusahaan ini kehilangan potensi sumber daya manusia. Contohnya saja Bukalapak, pada akhir 2019 start-up berstatus Unicorn ini memutuskan untuk melakukan PHK (Pemutusan Hubungan Kerja) atas 100 karyawannya dari berbagai divisi. Pemecatan ini dilakukan agar organisasi semakin ramping dan efisiensi kerja dalam perusahaan semakin tinggi. Dalam berita yang dituliskan CNBC Indonesia, dilaporkan bahwa direksi Bukalapak melakukan PHK ini demi kelangsungan perusahaan. Fokus Bukalapak kini bukan sekedar pertumbuhan, melainkan membangun perusahaan yang berkelanjutan. Demi mencapai tujuan ini, Bukalapak pun harus memaksimalkan sumber daya yang mereka punya termasuk sumber daya manusia agar kinerja setiap divisi dalam perusahaan semakin efektif dan efisien. Bukalapak menjadi contoh nyata bagaimana pengelolaan sumber daya manusia dalam suatu perusahaan, khususnya perusahaan start-up, menjadi sangat penting, khususnya di masa kini.

Berdasarkan latar belakang yang sudah disampaikan di atas, penulis tertarik untuk menelaah dan menuliskan tentang cara mengelola sumber daya manusia dalam dunia digital khususnya dalam mengelola bisnis start-up bidang jasa. Pengelolaan dan pengembangan sumber daya manusia di masa kini, khususnya di perusahaan start-up, memerlukan strategi dan proses yang tepat. Maka rumusan masalah yang ingin penulis angkat dalam Penelitian ini adalah: bagaimana cara mengelola sumber daya manusia dalam dunia digital untuk memperoleh sumber daya manusia yang unggul, khususnya dalam mengelola bisnis start-up bidang jasa? Apa saja aspek yang perlu diperhatikan?

\section{Metode Penelitian}


Penelitian ini, penulis menggunakan metode penelitian deskriptif kualitatif. Penelitian kualitatif dilakukan ketika peneliti ingin mengeksplorasi fenomena-fenomena yang tidak dapat dikuantifikasikan, yang bersifat deskriptif (Satori \& Komariah, 2013) Selain itu penelitian kuantitatif sebagai sebuah metode penelitian sesungguhnya dilandaskan pada filsafat post-positivisme, dimana peneliti berusaha untuk meneliti objeknya di dalam kondisi alamiah, dengan melakukan analisis yang bersifat baik induktif maupun deduktif dengan langsung melihat dan meninjau fenomena yang ada (Sugiyono, 2012). Di sisi lain lagi, Nana Syaodih (Sukmadinata, 2011) mengungkapkan bahwa penelitian deskriptif kualitatif memiliki maksud untuk mendeskripsikan dan menggambarkan fenomena-fenomena yang ada, baik yang bersifat alamiah maupun rekayasa manusia, yang lebih memperhatikan mengenai karakteristik, kualitas, dan keterkaitan antar kegiatan. Penelitian kualitatif deskriptif tidak memberikan perlakuan, manipulasi atau pengubahan pada variabel-variabel penelitannya, melainkan enggambarkan suatu kondisi yang apa adanya.

Dari rangkaian keterangan ahli di atas, dapat ditarik kesimpulan bahwa penelitian dengan bentuk deskriptif kualitatif merupakan penelitian yang cenderung apa adanya, dilandaskan studi pustaka yang kuat dan hasilnya lebih menekankan pada makna dan deskripsi teoritis. Di sini, penulis menggunakan metode ini karena penulis ingin mengeksplor fenomena pengelolaan sumber daya manusia di organisasi modern yang ada di era digital ini dengan lebih luas dan ingin memberikan pemaknaan, deskripsi dan analisa teoritis yang kuat akan fenomena ini, sehingga bisa memberikan kesimpulan yang tepat guna bagi organisasi atau perusahaan yang membutuhkannya.

\section{Hasil dan Pembahasan}

Cepatnya pertumbuhan dan perkembangan teknologi di era ini, salah satu kesalahan yang mungkin dilakukan perusahaan khususnya perusahaan start-up adalah memusatkan pikiran dan tenaganya hanya pada pengembangan teknologi yang mereka gunakan. Kecenderungan ini tidak dapat dihindari. Kerasnya persaingan ekonomi dan bisnis yang menggunakan teknologi sebagai basisnya, maka siapa yang memiliki dan menguasai teknologi terkini adalah mereka yang memiliki kemungkinan besar menang dalam persaingan. Akan tetapi jika penulis boleh berargumen, teknologi bukanlah pusat dari bisnis dan ekonomi. Bagi penulis teknologi bukanlah apa-apa tanpa manusia dibaliknya. Maka kunci dari kesuksesan sebuah bisnis, khususnya bisnis start-up, pertama-tama bukanlah pada teknologi yang digunakan melainkan pada sumber daya manusia yang mengoperasikannya.

Inilah yang membuat peranan HRD menjadi sangat krusial dalam sebuah perusahaan. HRD adalah pusat dari komponen yang paling penting dan tak tergantikan. Teknologi bisa ditiru dan digantikan dengan yang baru, akan tetapi jika kita berbicara tentang manusia, bisa jadi peranan seorang karyawan spesial tidak mudah untuk digantikan dan ditiru oleh karyawan lain. Dan bayangkan saja, menggabungkan sumber daya manusia yang kompeten dengan kemajuan teknologi yang luar biasa tentu akan menghasilkan workforce yang sulit disaingi.

Seperti yang sudah disampaikan pada latar belakang, pada penelitian ini penulis hanya akan fokus pada pengembangan sumber daya manusia pada perusahaan start-up bidang jasa. Mengapa? Apakah perusahaan start-up bidang produk dan jasa itu berbeda pengelolaannya? Jawabannya adalah ya. Fungsi karyawan pada perusahaan start-up yang menghasilkan 
produk jauh berbeda dibandingkan fungsi karyawan pada perusahaan start-up bidang jasa. Keragaman divisi dalam keduanya pun sangat berbeda, karena keduanya menawarkan output dan tujuan yang berbeda. Maka pengelolaan sumber daya manusia dalam kedua jenis ini pun akan berbeda.

Mari kita masuk pada point utama pada tulisan ini. Bagaimana cara menghasilkan sumber daya manusia yang unggul dalam perusahaan start-up bidang jasa di tengah berkembangnya era digital seperti sekarang ini? Untuk menghasilkan sumber daya manusia yang unggul, penulis menawarkan beberapa poin argumen yang akan membantu kita menjawab pertanyaan di atas, yaitu:

1. Menyinergikan HRD dalam sistem kerja perusahaan

2. Menempatkan SDM sebagai Strategic Value di perusahaan

3. Memotivasi karyawan guna meningkatkan kinerja

4. Penggunaan teknologi dalam manajemen sumber daya manusia

Penulis akan menerangkan keempat poin ini satu per satu.

\section{HRD dan Sistem Kerja Perusahaan Start-up}

Pada awal 1990, saat internet mulai memasuki dunia ekonomi dan bisnis, ia mengubah banyak hal. Internet merobohkan banyak dinding kompetisi konvensional yang sudah ada begitu lama. Peluang bisnis menjadi begitu luas dan tidak lagi terhalang batas geografis dan waktu. Bisnis tidak lagi ter-sentralisasi pada satu wilayah. Area kerja perusahaan menjadi semakin luas, tidak lagi harus berada di tempat yang sama. Banyak perusahaan yang sudah mulai menggunakan peralatan hi-tech, yang memungkinkan karyawan untuk berkomunikasi dengan lebih cepat dan luas. Virtual work pun mulai bermunculan dan diimplementasikan dalam operasi sehari-hari perusahaan.

Sisi pengelolaan sumber daya manusia pun berubah. HRD dituntut untuk mengembangkan sistem yang mampu mengelola karyawan dengan scope yang luas namun tetap dengan komando sentral yang stabil. Dengan tenaga kerja yang semakin beragam baik dari lokasi, jenis kelamin, ras, kemampuan/skills, harapan dan budaya, perusahaankhususnya HRD dipaksa untuk meningkatkan kemampuannya dalam mengelola data personal karyawan. Bukan hanya itu, HRD pun harus mampu membuat karyawan yang beragam ini merasa mampu bersaing sekaligus paham dengan visi dan misi perusahaan di mana ia bekerja.

Mungkin kita sudah tahu, bahwa sebelum disebut dengan sebutan HRD, divisi atau bagian perusahaan yang bertugas mengelola karyawan disebut sebagai divisi personalia. Perubahan dari personalia ke HRD pun bukan tanpa alasan. Untuk mengimbangi perkembangan bisnis yang ada, perusahaan tidak lagi dapat menyepelekan sumber daya manusia. Fungsi personalia yang biasanya hanya mengurus soal data karyawan dan gaji pun semakin berubah. Pekerjaan dan kewajibannya semakin kompleks. HRD ketambahan tugas dan peranan sebagai divisi yang bertanggung jawab atas pengelolaan dan pengembangan kemampuan karyawan, mulai dari awal ia direkrut hingga ia pensiun. Perusahaan tidak lagi dapat melihat HRD sebagai beban pengeluaran semata. Perusahaan harus mengubah pola pikirnya dan mulai memandang HRD sebagai rekan investasi, di mana di HRD lah perusahaan berinvestasi soal sumber daya manusianya. Tidak jarang perusahaan meminta data-data krusial untuk mengambil keputusan dari HRD. Karena sekali lagi tidak dapat 
dipungkiri bahwa karyawan menentukan masa depan perusahaan.

Inilah yang membuat penulis merasa bahwa penting bagi perusahaan untuk melibatkan HRD secara mendalam dalam sistem kerja perusahaan. Jika HRD diletakkan di luar sistem dan struktur kerja perusahaan, HRD tidak akan mampu bergerak secara maksimal. HRD membutuhkan link atau koneksi ke executives dan pemegang kekuasaan di perusahaan, HRD harus mengetahui keputusan yang mereka ambil, bagaimana tenaga kerja menjalani kesehariannya dan celah mana yang bisa dimasuki oleh HRD untuk terus mengembangkan karyawan. Integrasi HRD dengan keseluruhan ruang kerja dalam perusahaan adalah kuncinya.

Apakah ini mudah dilakukan? Jawabannya tentu saja tidak. Pada kenyataannya, banyak perusahaan yang kurang bahkan tidak mau melibatkan HRD terlalu jauh dalam proses kerja mereka. Baik di level karyawan hingga manajer, cenderung membatasi interaksinya dengan HRD. Hal ini dikarenakan banyak yang merasa bahwa dengan melibatkan HRD dalam kerja mereka, proses dan fase yang mereka harus lalui menjadi semakin panjang dan berbelit-belit. Inilah yang membuat banyak manajer yang justru lebih suka mengambil keputusan sendiri. Misalkan saja dalam proses mencari karyawan. Kebanyakan perusahaan hanya akan melibatkan HRD dalam proses recruitment-wawancara, negosiasi dan orientasi karyawan, akan tetapi tidak dalam proses perencanaannya. Maksud dari perencanaan di sini adalah proses ketika membahas karyawan seperti apa yang dibutuhkan, dimana akan diposisikan, fungsi jangka panjangnya apa, lebih baik mengambil fresh graduate atau professional. Halhal detail dalam proses perancanaan inilah yang sesungguhnya membutuhkan proses lebih serius dan di sanalah HRD seharusnya dilibatkan. Dalam perusahaan start-up bidang jasa lebih lagi, proses perencanaan sumber daya manusia haruslah disesuaikan dengan kebutuhan utama dan target perusahaan, di mana dalam praktiknya sangat dinamis tergantung keadaan pasar yang berubah-ubah. Keterlibatan HRD dalam proses perencanaan pengelolaan sumber daya manusia di perusahaan start-up yang menawarkan jasa sebagai produknya harus lebih berhati-hati. Menempatkan orang yang salah dalam posisi yang salah dapat berakibat fatal bagi masa depan perusahaan. Di tengah persaingan yang ganas dan tidak mengenal ampun, perusahaan harus lebih waspada, cerdik, dan cermat dalam mengelola sumber daya manusia yang mereka miliki.

HRD harus memperbaiki system kerja mereka dengan lebih efektif dan efisien. Secara kasar dapat dikatakan bahwa HRD harus dapat berbicara dan bekerja dalam 'bahasa' yang dimengerti oleh key member dari perusahaan. Bagaimana caranya? Salah satu langkah awal adalah dengan menjadi satu dengan karyawan dan kesehariannya. Associates atau perwakilan dari tim HRD harus ada di dalam setiap bagian perusahaan, mengobservasi keseharian mereka, mempelajari pola kerja mereka dan menganalisis kemungkinan terbaik untuk bisa mengelola sumber daya manusia yang ada. Kuncinya adalah dengan memberikan tools dan options yang tepat pada users yang tepat. Inilah bentuk transformasi HRD yang mungkin dilakukan bagi perusahaan. HRD memberikan pada perusahaan akses yang lebih baik akan informasi sumber daya manusianya, sehingga di saat informasi ini diperlukan perusahaan untuk pengambilan keputusan, HRD sebagai partner perusahaan tidak ragu lagi akan dilibatkan sebagai mitra kerja yang handal, efektif dan efisien.

Inilah Human Resources Information System (HRIS). Sistem ini penting untuk digunakan oleh perusahaan start-up untuk memaksimalkan kinerja mereka dan bersaing 
dengan lebih cerdas di pasar ekonomi. Prinsipnya sederhana, dengan data yang lebih baik maka informasi yang didapatkan juga akan lebih baik. Dengan informasi yang lebih baik, maka keputusan yang diambil juga akan menjadi lebih baik. Dan ini adalah hal utama yang dibutuhkan dalam perusahaan start-up. Dalam kesehariannya, banyak sekali keputusan yang harus diambil perusahaan. Maka peran HRD dalam HRIS ini akan banyak membantu pengambil keputusan untuk bisa menjadi semakin baik dalam mengambil keputusan. Pengambilan keputusan yang baik akan membuat penggunaan sumber daya manusia maksimal dan menciptakan sumber daya manusia yang unggul di perusahaan (Prihantoro, 2015).

\section{SDM sebagai Strategic Value di Perusahaan Start-up}

Aspek lain yang banyak berubah setelah masuknya teknologi dan digitalisasi dalam dunia bisnis adalah soal business and strategic value. Semakin banyak perusahaan yang menyadari bahwa untuk mencapai tujuan dari bisnis mereka, pengelolaan sumber daya yang mereka miliki harus tepat dan strategis. Mereka harus memberikan value kepada setiap sumber daya mereka dan menggali kesempatan untuk mengubah setiap aset dan sumber daya yang mereka miliki sebagai peluang di pasar. Hal inilah yang membuat banyak perusahaan mulai menggunakan system outsourcing untuk memenuhi kebutuhan back-office yang tidak seberapa penting, dan kemudian lebih memfokuskan dana dan sumber daya untuk keperluan yang lebih mendesak dan penting. Maka tidak jarang kita melihat banyak muncul perusahaan outsourcing untuk kebersihan, keamanan, dll. Menggunakan outsourcing untuk mengisi posisi yang tidak utama, maka perusahaan lebih bisa fokus memikirkan hal yang lebih penting.

Metode pengelolaan sumber daya ini, khususnya yang berkaitan dengan sumber daya manusia dikenal dengan sebutan Human Capital Management (HCM). HCM menjadi aspek yang penting dibandingkan dengan sumber daya lain. Karyawan berbeda dengan sumber daya yang lain. Pengelolaannya lebih kompleks dan sulit. Inilah yang membuat HRD harus pula bertransformasi dalam mengelola aset paling menantang di perusahaan ini (Suhariadi, 2013).

Perusahaan start-up cenderung memiliki personel yang sedikit, modal lebih kecil dan tingkat kompetisi yang tinggi. Sekitar 30-60 persen dari revenue mereka digunakan dan dihabiskan untuk HCM. Maka dari itu seorang pemimpin perusahaan start-up harus memahami bagaimana dana ini dihabiskan dan apakah investasinya berguna. Tugas inilah yang kemudia jatuh tidak lain pada HRD. HRD sekali lagi harus membuktikan dirinya sebagai rekan/mitra/partner kerja perusahaan yang bekerja maksimal. Masalahnya, sesungguhnya pengelolaan sumber daya manusia dalam HCM bukan hanya tugas dari HRD saja, melainkan juga tugas dari semua orang dalam perusahaan.

Sebuah organisasi atau perusahaan yang menerapkan HCM harus paham bahwa memaksimalkan sumber daya manusia atau tenaga kerja merupakan tugas semua pihak, mlai dari CEO, board members, eksekutif, manajer departemen, dan bahkan setiap karyawan yang ingin perusahaan berkembang. Setiap pihak memiliki peran untuk memaksimalkan value dan kontribusi tenaga kerja di perusahaan. Mengapa? Karena SDM merupakan strategic value di perusahaan. Tugas HRD adalah untuk menjadi 'pengemudi dalam mobil' saja. HRD berfungsi untuk mengarahkan dan menyelaraskan strategi HCM perusahaan dengan tujuan dan sasaran yang ditetapkan. Untuk melakukan ini HRD harus memiliki teknologi dan 
kemampuan yang tidak hanya mampu menyediakan bagi perusahaan informasi personal setiap karyawan, namun juga informasi tentang produktivitas dan value nya bagi perusahaan.

Inilah mengapa HRD berperan penting dalam peletakan strategic value sebuah perusahaan. HRD dan sumber daya manusia tidak bisa dipandangan hanya sekedar sebagai cost dalam bisnis. HRD dan tenaga kerja adalah bagian dari strategic value perusahaan untuk meraih kesuksesan. Semakin mampu perusahaan memaksimalkan human capital-nya semakin besar kemungkinan perusahaan menang dalam kompetisi.

Salah satu elemen kunci bagi HRD untuk menciptakan strategic value yang tepat adalah dengan menempatkan orang yang tepat pada bidang yang tepat di seluruh bagian perusahaan. Pemimpin perusahaan harus merespon cepat perubahan dalam bisnis dengan mengambil keputusan yang tepat. Keputusan yang tepat hanya dapat diambil ketika pemimpin dapat berdikusi dengan karyawan yang tepat. Maka keterlibatan karyawan dalam pekerjaannya haruslah tinggi. Karyawan harus mau terlibat dalam setiap aspek pekerjaannya dan memberikan fokus yang maksimal. Karyawan harus memahami dengan jelas apa tujuan dan sasaran perusahaannya, kemudian bekerja bersama-sama untuk mencapainya (Merry et al., 2014).

Karyawan merupakan strategic value yang sangat berharga terlebih bagi sebuah bisnis start-up. Hal ini berdasarkan sulitnya atau bahkan tidak mungkin untuk meniru (to copy) talenta dan skill yang dimiliki karyawan. Selain talenta dan skill, relasi dan chemistry antar karyawan dalam sebuah perusahaan start-up juga tidak bisa ditiru dengan mudah. Kedua hal ini adalah sebuah ciri khas yang bisa dibentuk dan dibina dari karyawan sebuah perusahaan start-up dan belum tentu bisa diberlakukan di start-up lainnya. Jika kita berbicara teknologi, produk, jasa, semuanya dapat ditiru dengan mudah. Hanya sumber daya manusia yang bisa menjadi ciri khas sebuah start-up. Maka dari itulah penempatan sumber daya manusia sebagai strategic value dalam pengembangan perusahaan adalah cara berkompetisi yang harus difokuskan perusahaan start-up yang ingin bersaing dalam jangka panjang.

\section{Peran Motivasi dan Kinerja Karyawan}

Ada berbagai cara yang dapat dilakukan untuk memotivasi karyawan. Secara umum, penulis mengelompokkan dua metode utama yang biasa dilakukan untuk memacu motivasi karyawan: insentif finansial dan insentif non-finansial. Secara garis besar, insentif finansial dapat berupa: bonus, gaji, uang lembur, tunjangan, dana pensiun, dll. Sedangkan insentif nonfinansial dapat berupa: rotasi kerja, kenaikan pangkat, pengayaan kerja, seminar, promosi, dll.

Walaupun banyak pemikir seperti Herzberg percaya bahwa uang bukanlah bentuk motivasi positif bagi seorang karyawan, namun tidak dapat dipungkiri bahwa system gaji dan tunjangan diciptakan untuk memotivasi karyawan. Salah satu hasil dari bekerja adalah bayaran yang diterima pegawai, sebuah bentuk apresiasi dari kerja yang dilakukan untuk perusahaan. Maka logis jika dikatakan bahwa dengan menaikkan bayaran, bonus, ataupun insentif karyawan, maka kinerja karyawan juga akan terpacu menjadi lebih baik. Maka tidak salah jika selama bertahun-tahun perusahaan telah menerapkan peningkatan insentif finansial sebagai upaya meningkatkan motivasi karyawannya (Ibrahim \& Paulus, 2016).

Akan tetapi di era millennial seperti sekarang ini, keadaan telah banyak berubah. Gaji bukanlah segalanya bagi seorang karyawan. Banyak anak muda yang tidak lagi menempatkan 
besarnya bayaran sebagai prioritas utama dalam memilih suatu pekerjaan. Kenyamanan lingkungan kerja, fleksibilitas pekerjaan, pengalaman yang akan didapat, kesempatan promosi dan pengembangan diri, merupakan sedikit dari sekian banyak prioritas anak muda dalam mencari pekerjaan, terutama dalam perusahaan start-up. Karena hal ini pula, hampir setiap perusahaan start-up yang ada selalu sebisa mungkin membuat tempat dan aturan kerja mereka sesuai dengan harapan anak-anak muda masa kini. Tidak lagi ada kotak-kotak tempat kerja, tidak lagi ada jam baku bekerja, dan bahkan tidak ada lagi batasan cara untuk melakukan sebuah pekerjaan. Para pekerja di perusahaan start-up biasanya boleh bekerja di mana pun mereka mau, pada jam apapun dan dengan cara yang mereka suka. Hal yang diutamakan perushaan start-up bukan lagi soal how it is done, melainkan sudah semakin mengarah ke what is the result. Perusahaan menetapkan goal atau tujuan yang harus dicapai karyawannya dan inilah standart penilaian perusahaan terhadap karyawannya (Budihardjo, 2015).

Cara model baru ini terbukti sangat efektif dalam memacu karyawan millennial. Metode ini membuat mereka lebih termotivasi dalam bekerja dan dapat bekerja dengan lebih efektif dan efisien. Inovasi -inovasi era millennial inilah yang seharusnya dikembangkan perusahaan start-up jika ingin bersaing mendapatkan sumber daya manusia yang unggul untuk perusahaan mereka. Tidak dapat dipungkiri bahwa bayaran/ gaji merupakan aspek yang tidak boleh disingkirkan begitu saja. Tapi perhatian perusahaan start-up harus lebih diutamakan pada bagaimana cara membuat karyawannya nyaman dalam bekerja serta termotivasi lewat non-financial incentives. Jika aspek ini terpenuhi, maka baru besaran gaji mengikuti hasil capaian karyawannya. Cara baru ini penulis yakin dapat menghadirkan warna baru dalam pengolahan motivasi sumber daya manusia di perusahaan. Untuk mencegah karyawannya menerima tawaran kerja dan pindah ke perusahaan pesaing, maka pertama-tama yang harus ditingkatkan bukanlah gajinya, melainkan rasa nyaman pekerja itu di perusahaan dan motivasi bekerjanya. Jika dua aspek ini sudah meresap dalam diri seorang karyawan, maka tidak akan mudah seorang karyawan berpindah ke tempat lain.

Lalu bagaimana pola yang tepat untuk digunakan dalam memotivasi karyawan? Bagi penulis keseimbangan antara non-financial incentives dan financial incentives adalah cara yang paling tepat untuk memotivasi karyawan. Seperti dikatakan Abraham Maslow dalam hierarcy of needs-nya, ada kebutuhan-kebutuhan dasar manusia yang harus dicapai terlebih dahulu sebelum manusia beranjak ke level kebutuhan lainnya. Jika perusahaan - khususnya perusahaan start-up —mau memotivasi karyawan, mulailah dari hal ini dahulu. Beri karyawan gaji yang cukup dan layak untuk hidup. Tapi pada titik tertentu, perusahaan harus bergerak memenuhi level kebutuhan karyawan yang lain dan usahakan karyawan mampu bergerak mencapai level kebutuhan tertinggi. Jikalau karyawan sudah mencapai level kebutuhan tertinggi yang notabene non-financial-maka tidak akan ada hal lain yang membuat seseorang butuhkan lagi. Dengan demikian, walaupun perusahaan lain menawarkan hal-hal lain, kemungkinan seorang karyawan tergerak untuk berpindah akan kecil adanya.

Kemudian penting bagi seorang pemimpin perusahaan start-up untuk memahami pentingnya rasa percaya dan kultur positif dalam perusahaan. Melihat keadaan perusahaan start-up masa kini, jelas terbukti bahwa Teori X yang dipaparkan Douglas McGregor tidak tepat digunakan sebagai mindset seorang pemimpin perusahaan start-up. Perusahaan start-up cenderung mengayomi kultur bebas bertanggung-jawab. Karyawan pada perusahaan start-up 
yang kebanyakan anak muda tidak suka dikekang. Mereka lebih suka bekerja dengan cara mereka, asal pekerjaan mereka selesai dan dilakukan dengan baik. Maka Teori Y lebih tepat untuk diterapkan dalam perusahaan start-up. Seorang pemimpin perusahaan start-up, dengan menerapkan teori Y dalam perusahaannya, akan membuat motivasi karyawannya cenderung meningkat. Memberikan kepercayaan yang cukup pada karyawan akan membuat karyawan merasa nyaman dalam bekerja. Rasa nyaman ini pada akhirnya akan meningkatkan motivasi karyawan untuk terus bekerja untuk perusahaan.

\section{E-HRD: Bentuk Terkini Manajemen Sumber Daya Manusia}

Karyawan perusahaan start-up tidak bisa dilepaskan kesehariannya dari teknologi dan dunia digital. Sudah jelas bahwa mereka yang mau bekerja di dalam perusahaan start-up harus tahu cara mengoperasikan teknologi. Maka dari itu dalam poin yang terakhir ini menyarankan sebuah metode pengelolaan sumber daya manusia di perusahaan start-up, yang berbalut teknologi masa kini. Inilah yang disebut E-HRD.

Pengelolaan SDM sudah banyak berubah dari masa ke masa. Teknik yang digunakan pun sudah banyak berubah, sejak masih menggunakan lembaran kertas untuk mendata hingga sekarang sudah mulai banyak digunakan IVR (intelligence voice response). Setiap harinya dunia HRD berkembang dan maju dan tidak ada yang tahu sampai mana batas perkembangannya.

Sekarang, tidak asing lagi kita temukan banyak HRD perusahaan yang sudah mulai menggunakan internet sebagai jalan berkomunikasi dengan karyawannya. Dari segi positif, manajer perusahaan akan lebih mudah mengakses informasi seputar karyawan kapan pun dan di mana pun, yang bermuara pada proses manajemen yang lebih cepat. Para karyawan pun dimudahkan, sistem ini juga memungkinkan mereka mengatur karier mereka dan memungkinkan mereka bersaing dengan lebih cekatan dalam pekerjaan. Akan tetapi dari segi negatif, teknologi ini dapat berimbas pada terkurungnya HRD dari karyawannya: tatap muka jadi berkurang, HRD tidak dapat melihat secara murni dan apa adanya seorang karyawan, serta sisi kemanusiaan terkadang terbatasi dengan data yang ada pada komputer semata. Maka ada beberapa contoh E-HRD yang penulis rasa sangat penting untuk diterapkan dalam perusahaan start-up masa kini agar dapat menciptakan sumber daya manusia yang unggul, yaitu Portal E-HRD, employee and managerial self-service, artificial intelligence.

\section{Portal E-HRD}

Portal E-HRD menyediakan situs yang dapat dikunjungi oleh karyawan untuk berkomunikasi dengan HRD perusahaan. Portal E-HRD ini bisa beragam bentuknya, mulai dari yang sederhana dan sebatas mengelola data karyawan, hingga portal yang sanggup menyediakan tampilan personal bagi setiap karyawan layaknya media sosial. Fungsi portal EHRD ini pun beragam, mulai dari yang hanya bisa mengelola pertanyaan dan keluhan karyawan, hingga portal yang sanggup mengelola da menampilkan data kompleks karyawan seperti besaran gaji, tanggal presensi, jenjang karier, dsb. Portal E-HRD biasanya dapat diakses dengan menggunakan akun yang dimiliki setiap karyawan. Tampilan dan akses yang dimungkinkan setiap akun pun berbeda. Akun karyawan dan akun manajer akan memiliki opsi berbeda. Bentuk portal akan disesuaikan dengan peran karyawan tersebut di perusahaan. (contoh portal ada di gambar 1) Perusahaan start-up masa kini sudah harus mulai memikirkan 
pengelolaan sumber daya manusia dengan teknologi digital seperti ini. Selain menghemat biaya dan waktu, pengelolaan sumber daya manusia pun menjadi semakin menarik dan menggugah motivasi karyawan.

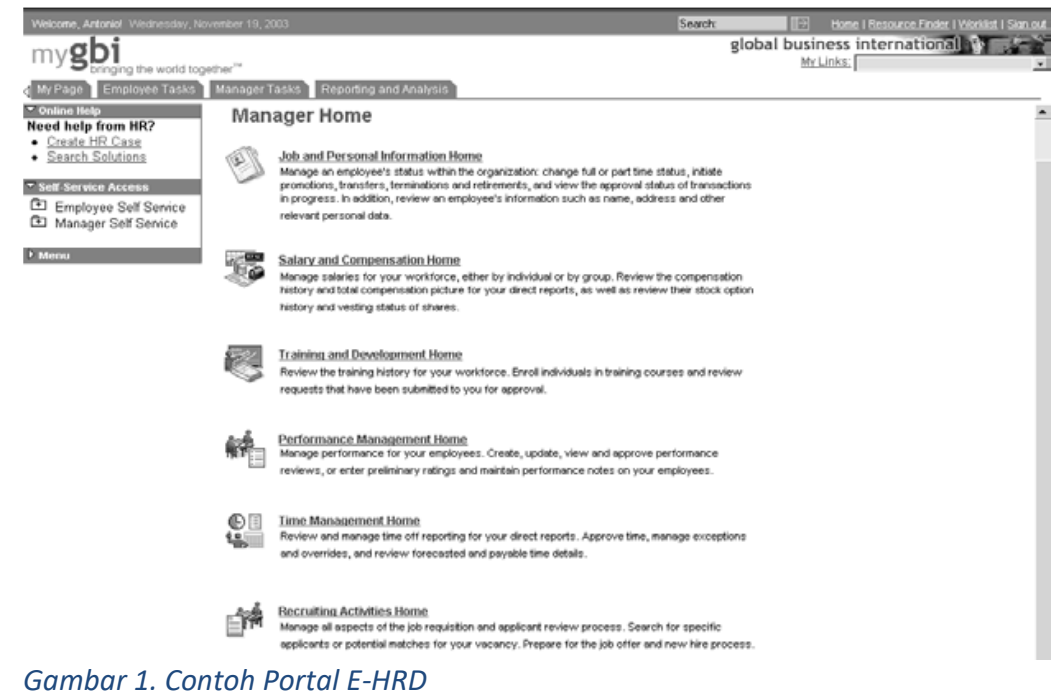

Portal E-HRD semacam ini dapat menjadi sarana penting untuk membangun employee brand di perusahaan start-up. Employee brand memberikan gambaran dan kesan bagi seorang karyawan akan bagaimana rasanya bekerja untuk sebuah start-up canggih. Konsep ini dapat menjadi daya tarik sendiri bagi karyawan perusahaan start-up dan memotivasinya untuk memberikan yang terbaik agar tetap dapat bekerja di perusahaan. Di dalam perusahaan start-up bidang jasa terutama, penggunaan portal E-HRD semacam ini akan sangat bermanfaat, dimana keseharian karyawan dan pekerjaannya akan dapat dengan mudah dipantau serta karyawan memiliki satu pintu untuk mengakses pekerjaan dan hasil kerjanya.

Portal E-HRD tentunya tidak hanya bermanfaat hanya bagi karyawan dan manajer saja. Kinerja HRD pun akan dipermudah dengan adanya portal ini. Portal E-HRD dapat menjadi jalan bagi HRD untuk menunjukkan produk kerja dan layanannya. Portal ini menempatkan HRD di dalam setiap aspek pekerjaan karyawannya di kesehariannya. Di dalam perusahaan start-up yang besar, yang sehari-harinya mengelola jutaan data pelanggan, portal ini juga dapat menjadi pengawas kinerja karyawan, agar tetap sesuai dengan aturan dan standar perusahaan.

\section{Employee and manager self-service}

Employee dan manager self-service adalah salah satu bentuk pelayanan HRD yang paling favorit. Secara mendasar, seperti arti kata self-service yang disematkan padanya, metode ini memungkinkan karyawan, baik pada level bawahan hingga manajer untuk mengelola pekerjaan dan karier mereka via program perusahaan. Perbedaan mendasar antara portal E-HRD dan program ini hanya terletak penggunaan internet sebagai basisnya. Secara mendasar, program employee dan manager self-service ini memungkinkan karyawan untuk:

- Memasukan informasi dan data diri karyawan seperti alamat, telepon, kontak darurat, dll.

- Mengakses slip gaji dan retirement options. 
- Menerima berita dan updates seputar perusahaan.

- Mengelola tunjangan dan program tambahan perusahaan seperti asuransi, tunjangan anak, opsi makanan cafetaria, dll.

- Mendaftarkan diri untuk training, pelatihan dan seminar tertentu.

- check-log jam masuk dan keluar kantor.

- Mengelola pengembangan diri karyawan.

- Mereview kinerja perusahaan, baik atasan maupun rekan kerja.

- Mengakses aturan dan by-law perusahaan.

- Menyelesaikan survey karyawan.

- Melihat peluang promosi.

- Mengambil tes diagnostic untuk pengembangan diri.

- Melaporkan hasil kerja.

- Berkomunikasi dengan HRD.

Opsi yang ada di dalam employee dan manager self-service ini bisa lebih beragam dan terkadang bahkan melebihi area kerja HRD. Maka biasanya opsi ini tepat untuk digunakan dalam perusahaan yang ingin membatasi atau mengurangi tenaga kerja di HRD mereka dan menyerahkan tugas pengelolaan sumber daya manusia pada manajer-manajer yang ada di perusahaan.

\section{Artificial intelligence program basis}

Siapa yang tidak mengenal kata artificial intelligence atau AI di masa ini. Banyak perangkat elektronik yang kita gunakan, hingga layanan internet yang kita nikmati, sudah menggunakan artificial intelligence sebagai program pendukungnya. Dalam jurnal Harvard Business Review dengan edisi "Artificial Intelligence for the Real World" (Davenport \& Ronanki, 2018) dikatakan bahwa AI secara mendasar didefinisikan sebagai: 'Computer systems to sense, reason, and respond to the environment'. Sistem computer dengan AI dapat terlibat untuk merasakan, menalar dan merespon situasi dan lingkungan tertentu, bahkan yang kompleks dan dinamis sekalipun.

Seperti halnya AI sudah banyak digunakan di dalam kehidupan manusia sehari-hari, dunia korporasi atau bisnis juga sudah mulai mengaplikasikan AI di dalam dunia pekerjaan dan pengelolaan karyawan. Organisasi kecil maupun besar terus menerus mencari cara untuk menggunakan AI sebagai daya ungkit dalam proses bisnis. Perusahaan start-up terutama, area kerjanya yang selalu berkaitan dengan dunia digital dan internet menuntut perusahaan startup untuk juga meng-update dirinya dengan teknologi terkini. Semakin banyaknya organisasi yang bersaing untuk mendapatkan tenaga kerja unggul, persaingan menjadi semakin ketat. Maka sangat penting bagi perusahaan start-up untuk memaksimalkan pengelolaan sumber daya manusia yang sudah mereka miliki dan membuat mereka betah bekerja di perusahaan. Inilah yang disebut dengan employee engagement, dimana karyawan secara menyeluruh terlibat dalam pekerjaannya.

Ada banyak definisi dari employee engagement. Secara umum, aspek yang ada di dalam employee engagement adalah antusiasme, semangat dalam bekerja, self-motivated, mau mengembangkan diri, dsb (Pranitasari, 2019). Seorang karyawan yang mau terlibat 
dalam pekerjaannya mampu menemukan makna dan tujuan dari pekerjaannya. Akan tetapi kebanyakan perusahaan mengalami kesulitan untuk membuat karyawannya terlibat. Bahkan dapat terjadi bahwa perusahaan membatasi akses karyawan pada annual review dan performance assessment mereka. Metode lama yang biasa digunakan untuk me-review karyawan seperti employee survers, data analysis, dan reviews seringkali justru merusak kinerja karyawan daripada memotivasinya.

AI mungkin adalah jawab dari permasalahan ini. AI menyediakan peluang dan jalan bagi perusahaan untuk meningkatkan keterlibatan karyawannya dengan cara yang menyenangkan namun juga efektif. Penggunaan AI dalam pengelolaan karyawan memodernisasi proses kerja dan pengalaman karyawan, sejak awal ia bergabung, mulai bekerja hingga pengembangan dirinya di perusahaan. Berikut penulis tawarkan beberapa jalan di mana AI dapat membantu meningkatkan produktivitas kerja di perusahaan start-up dan meningkatkan employee engagement dalam perusahaan tersebut

- Predictive analytics \& behavior mapping

Learning and development (L\&D) adalah salah satu faktor penting dalam meningkatkan employee engagement (Robbins \& Judge, 2013). Banyak perusahaan start-up sudah mulai menyadari hal ini dan mulai menyusun program pengembangan diri karyawan sebagai salah satu bagian dalam employee engagement. AI dapat digunakan untuk mengembangkan program ini dah bahkan membawa program ini ke level yang lebih tinggi. AI dapat digunakan untuk menganalisa dan memprediksi data dengan cepat dan memberikan output yang personal untuk setiap karyawan. AI memungkinkan analisis pola, kebiasaan dan kecenderungan karyawan dan memberikan kemungkinan output terbaik. Output ini dapat digunakan untuk merancang pelatihan personal bagi setiap karyawan sesuai dengan kebutuhannya. Dengan ini perusahaan dapat menghemat sumber dayanya. Seringkali seminar dan pelatihan yang dilakukan karyawan tidak berjalan efektif karena mungkin hanya sebagian karyawan yang membutuhkan namun pelatihan tersebut diwajibkan bagi semua karyawan karena perusahaan tidak memiliki basis yang memadai soal karyawan mana membutuhkan pelatihan apa.

Adanya AI ini perusahaan dapat memastikan pengembangan sumber daya manusianya berjalan efektif dan sesuai kebutuhan. Sumber daya manusia yang efektif dan efisien akan menciptakan sinergi yang kuat dalam budaya kerja perusahaan. AI dapat mendampingi setiap karyawan secara real-time dengan menciptakan program pelatihan yang adaptable, dapat disesuaikan dari waktu ke waktu. AI dapat berfungsi sebagai pelatih, instruktur sekaligus pengawas yang menemani karyawan sehari-harinya dalam pelaksanaan tugas mereka. Perlu diingat bahwa perusahaan tidak perlu mengeluarkan biaya besar untuk melaksanakan ini semua. Penggunaan AI sungguh dapat menunjang kinerja perusahaan sehingga dapat bersaing secara maksimal dalam bisnis, sekaligus menciptakan karyawan yang unggul.

- Responsive \& Real-time feedback tools

Kecepatan dan ketepatan adalah kunci dari keberhasilan bisnis digital. Begitu pula dengan menilai karyawan. Real-time feedback adalah gerbang bagi perusahaan untuk memahami apa yang terjadi di dalam benak karyawannya: apa yang mereka rasakan, bagaimana kesan mereka pada perusahaan, apakah mereka menyukai lingkungan dan atmosfer kerjanya, dll. Dengan menggunakan AI untuk sebagai otak dalam platform kerja karyawan, perusahaan dapat mengumpulkan informasi lengkap dari karyawan mereka dan 
mengatasi masalah yang muncul dengan cepat tanpa harus memakan banyak waktu dan sumber daya.

AI menjadi pendongkrak daya saing perusahaan start-up di masa kini. Dengan mendapatkan informasi dan menanggapi informasi dengan cepat dan tepat, laju perusahaan juga akan menjadi semakin cepat. Inilah salah satu kunci kesuksesan bisnis start-up di masa kini. Selain itu, responsive \& Real-time feedback tools memungkinkan perusahaan menjamin sumber daya manusia yang unggul dan siap bersaing.

\section{- Collaboration tools}

Sistem pengelolaan perusahaan yang berbasis AI dapat menyederhanakan sistem kerja sama dan kolaborasi dalam perusahaan. Biasanya, karyawan di dalam perusahaan start-up bekerja di dalam tim. Hampir tidak mungkin rasanya bahwa karyawan perusahaan start-up khususnya dalam bidang jasa, bekerja secara individual. Karyawan perusahaan start-up yang menyediakan jasa biasanya tidak bekerja di lapangan secara langsung. Tugas mereka biasanya merancang program, mengoperasikannya dan memantaunya dari jauh (remote). Karena luas dan banyaknya client atau user yang harus mereka pantau, biasanya kolaborasi yang baik dituntut dari karyawan agar hasil pekerjaan baik adanya.

Sekali lagi di sinilah AI dapat berperan penting. Penggunaan AI dalam sistem perusahaan membuat pola kerja sama ini menjadi semakin terpadu dan lancar. Mengapa bisa demikian? AI dapat diprogram untuk mengambil data karyawan tentang cara kerjanya, lalu memprediksikan dan menganalisis karyawan mana yang memiliki pola kerja serupa. Jika data ini sudah dikumpulkan, maka manajer kemudian dapat menempatkan karyawan dengan pola dan kecenderungan kerja serupa dalam tim yang sama. Jika orang dengan pola kerja yang sama bekerja dalam satu tim, kemungkinan mereka dapat bekerja sama dengan baik akan semakin tinggi.

Kolaborasi seringkali berarti bertemu, membahas dan mencari jalan keluar atas masalah bersama. Inilah yang membuat data hasil AI akan sangat membantu. AI dapat mengerjakan pengumpulan data karyawan seperti ini dengan lebih tepat (precise) dan akurat. Misalnya saja, dengan AI dapat mencocokkan kalendar setiap karyawan dalam satu tim dan menentukan jadwal temu yang paling cocok untuk semua anggota tim, atau AI dapat mengusulkan karyawan mana yang dapat dijadikan team leader dengan melihat data hasil kerja karyawan, hasilnya pun pasti adil, karena berdasarkan data bukannya nepotisme. Penggunaan AI dalam kolaborasi dapat mengatur jalannya proyek perusahaan, meningkatkan semangat karyawan sekaligus menjamin hasil kerja yang baik. Masih banyak potensi yang dapat mungkin dilakukan oleh AI, karena teknologi ini masih akan terus berkembang dan menjadi semakin pintar seiring dengan berjalannya waktu.

\section{Kesimpulan}

Dunia HRD di era digital ini seakan berada di tengah transformasi peran tanpa henti. Peran yang bukan hanya mengubah fungsi dari HRD sendiri, melainkan juga peran penting HRD di dalam bisnis. Bisnis start-up, khususnya yang bergerak dalam bidang penawaran jasa harus dapat beradaptasi dengan perubahan ini dengan baik untuk dapat bertahan di tengah persaingan usaha yang sangat tinggi.

Hal pertama yang perlu diperhatikan dalam transformasi ini tentunya adalah perihal sumber daya manusia dan bagaimana cara mengelolanya. Pusat dari sebuah bisnis jasa, dalam 
perusahaan start-up sekalipun adalah tenaga kerjanya. Teknologi memang penting, namun tanpa sumber daya manusia yang mampu menciptakan program dan menjalankannya, teknologi ini tidak akan memberikan dampak maksimal. Maka jawaban dari rumusan masalah yang penulis tawarkan di atas: 'bagaimana cara mengelola sumber daya manusia dalam dunia digital untuk memperoleh sumber daya manusia yang unggul, khususnya dalam mengelola bisnis start-up bidang jasa?', dapat dibagi menjadi beberapa bagian:

Pertama, sinergi antara HRD dan sistem kerja perusahaan. HRD harus hadir di dalam keseharian kerja karyawan perusahaan, memantau bagaimana mereka bekerja, bagaimana pola pengambilan keputusan mereka, dan mencari celah untuk melakukan aksi yang dirasa perlu. Jika HRD diletakkan di luar struktur dan sistem kerja perusahaan, HRD akan menjadi terisolasi dan tidak akan mampu memberikan banyak dampak di perusahaan. Kontribusi HRD yang paling penting adalah memberikan tools dan options yang tepat pada users yang tepat. Maka HRD harus dianggap sebagai partner dan mitra kerja. HRD jangan hanya dianggap sebagai beban pengeluaran perusahaan, melainkan salah satu jalan perusahaan berinvestasi pada sumber daya manusianya.

Kedua, meletakkan SDM sebagai Strategic Value dalam perusahaan. Pengelolaan sumber daya manusia, yang dalam dunia bisnis dikenal dengan sebutan Human Capital Management (HCM), adalah hal yang paling penting dalam perusahaan. Sebuah organisasi atau perusahaan yang menerapkan HCM harus paham bahwa memaksimalkan sumber daya manusia atau tenaga kerja merupakan tugas semua pihak, mlai dari CEO, board members, eksekutif, manajer departemen, dan bahkan setiap karyawan yang ingin perusahaan berkembang. Setiap pihak memiliki peran untuk memaksimalkan value dan kontribusi tenaga kerja di perusahaan. Mengapa? HRD dan tenaga kerja adalah bagian dari strategic value perusahaan untuk meraih kesuksesan. Semakin mampu perusahaan memaksimalkan human capital-nya semakin besar kemungkinan perusahaan menang dalam kompetisi. kunci bagi HRD untuk menciptakan strategic value yang tepat adalah dengan menempatkan orang yang tepat pada bidang yang tepat.

Ketiga, memotivasi karyawan agar kinerjanya meningkat. Motivasi memiliki peranan penting dalam proses kerja karyawan. Karyawan yang termotivasi cenderung memiliki kinerja yang baik dan berperan besar terhadap kemajuan perusahaan. Ada berbagai cara yang dapat dilakukan untuk memotivasi karyawan. Secara umum, penulis mengelompokkan dua metode utama yang biasa dilakukan untuk memacu motivasi karyawan: insentif finansial dan insentif non-finansial. Secara garis besar, insentif finansial dapat berupa: bonus, gaji, uang lembur, tunjangan, dana pensiun, dll. Sedangkan insentif non-finansial dapat berupa: rotasi kerja, kenaikan pangkat, pengayaan kerja, seminar, promosi, dll. di era digital dan millennial seperti ini, gaji bukanlah segalanya bagi seorang karyawan. Kenyamanan lingkungan kerja, fleksibilitas pekerjaan, pengalaman yang akan didapat, kesempatan promosi dan pengembangan diri, merupakan sedikit dari sekian banyak prioritas yang ditempatkan karyawan start-up. Bagi penulis keseimbangan antara non-financial incentives dan financial incentives adalah cara yang paling tepat untuk memotivasi karyawan.

Keempat, mengunakan E-HRD sebagai cara menjalankan manajemen sumber daya manusia dalam perusahaan. Mengelola karyawan di perusahaan start-up harus melibatkan teknologi di dalamya agar menjadi semakin efektif dan efisien. Ada beberapa contoh E-HRD yang penulis rasa sangat penting untuk diterapkan dalam perusahaan start-up masa kini agar 
dapat menciptakan sumber daya manusia yang unggul, yaitu Portal E-HRD, employee and managerial self-service, artificial intelligence. Ketika contoh E-HRD ini dengan kelebihan dan kekurangannya masing-masing dapat mengungkit kinerja HRD dalam mengelola karyawan perusahaan, sekaligus menjadikan mereka karyawan yang unggul dalam dunia kerja (Hasibuan, 2007). 


\section{Bibliografi}

Astuti, K. R. (2019). Infrastruktur Dan Teknologi Dorong Kemajuan Umkm. Forum Manajemen STIMI Handayani Denpasar, 17(2), 71-86.

Budihardjo, I. M. (2015). Panduan Praktis Penilaian Kinerja Karyawan. Raih Asa Sukses.

Davenport, T. H., \& Ronanki, R. (2018). Artificial intelligence for the real world. Harvard Business Review, 96(1), 108-116.

Fonna, N. (2019). Pengembangan Revolusi Industri 4.0 dalam Berbagai Bidang. Guepedia.

Hasibuan, M. S. P. (2007). Manajemen Sumber Daya Manusia Perusahaan. Bandung: PT. Bumi Aksa.

Ibrahim, M., \& Paulus, D. (2016). Pengaruh Pemberian Insentif terhadap Kinerja Karyawan (Kasus pada Karyawan Bagian Produksi Pabrik Kelapa Sawit di PT. Rohul Sawit Industri Kabupaten Rokan Hulu Provinsi Riau). Riau University.

Merry, L., Ginting, M., \& Marpaung, B. (2014). Pemilihan supplier buah dengan pendekatan metode Analytical Hierarchy Process (AHP) dan TOPSIS: Studi kasus pada perusahaan retail. Teknik Dan Ilmu Komputer, 3(9), 48-58.

Pranitasari, D. (2019). Keterikatan Kerja Dosen Sebagai Kunci Keberhasilan Perguruan Tinggi. Deepublish.

Prihantoro, A. (2015). Peningkatan Kinerja Sumber Daya Manusia Melalui Motivasi, Disiplin, Lingkungan Kerja, Dan Komitmen. Deepublish.

Reza, T. S., \& Hermawansyah, W. (2019). Masa Depan Bisnis Kreatif di Era Revolusi Industri 4.0 Ditinjau dari Kebijakan Sektor Publik, Bisnis dan Perpajakan. Majalah Ilmiah Bijak, 16(1), 48-52.

Riniwati, H. (2016). Manajemen Sumberdaya Manusia: Aktivitas Utama dan Pengembangan SDM. Universitas Brawijaya Press.

Robbins, S. P., \& Judge, T. A. (2013). Organizational behavior (Vol. 4). New Jersey: Pearson Education.

Satori, D., \& Komariah, A. (2013). Metodologi penelitian kualitatif. Bandung: Alfabeta, 22.

Savitri, A. (2019). Revolusi Industri 4.0: Mengubah Tantangan Menjadi Peluang di Era Disrupsi 4.0. Penerbit Genesis.

Sugiyono. (2012). Metode Penelitian Kuantitatif, Kualitatif dan R \& D.Bandung:Alfabeta. Metode Penelitian Kuantitatif, Kualitatif Dan $R \quad \& \quad$ D.Bandung:Alfabeta. https://doi.org/10.1017/CBO9781107415324.004

Suhariadi, F. (2013). Manajemen Sumber Daya Manusia: Dalam Pendekatan TeoretisPraktis. Airlangga University Press. 
Sukmadinata, N. S. (2011). Metode Penelitian Pendidikan. PT. Remaja Rosdakarya.

Widodo, I. H. D. S. (2020). Membangun Startup Entrepreneur yang Unggul. Penebar Media Pustaka. 